The Invention of the Brazilian Northeast 


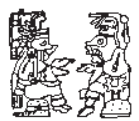

A BOOK IN THE SERIES

Latin America in Translation / En Traducción / Em Tradução

Sponsored by the Duke University-University of North Carolina

Program in Latin American Studies 


\section{The Invention of the}

\section{BRAZILIAN NORTHEAST}

\section{DURVAL MUNIZ DE ALBUQUERQUE JR.}

WITH A FOREWORD BY JAMES N. GREEN

TRANSLATED BY JERRY DENNIS METZ

DUKE UNIVERSITY PRESS

Durham and London 2014 
English translation (C) 2014 Duke University Press

Portuguese edition published by Cortez Editora

(C) 1999 by Cortez Editora

All rights reserved

Printed in the United States of America on acid-free paper $\infty$

Designed by Natalie F. Smith

Typeset in Scala Pro by Westchester Publishing Services

Cover art: Collage by Natalie F. Smith based on a photograph of a railway bridge between São Félix and Cachoeira, near Salvador,

Brazil. Photograph (C) dbimages / Alamy.

\author{
Library of Congress Cataloging-in-Publication Data \\ Albuquerque Jr., Durval Muniz de (Albuquerque Junior) \\ [Invengco do nordeste e outras artes. English]
}

The invention of the Brazilian Northeast / Durval Muniz de Albuquerque Jr. ; with a foreword by James N. Green ; translated by Jerry D. Metz.

pages $\mathrm{cm}$-(Latin America in translation/en traducción/em tradução)

Includes bibliographical references and index.

ISBN 978-0-8223-5770-4 (cloth : alk. paper)

ISBN 978-0-8223-5785-8 (pbk. : alk. paper)

1. Brazil, Northeast-History. 2. Brazil, Northeast-Social conditions. I. Title.

11. Series: Latin America in translation/en traducción/em tradução.

F2583.A54132014 981-dc23 2014015441 
For my mother, Maria, who reared me a nordestino but also led me to dream of São Paulo, with the same longing I feel for it today. 
